\title{
OSNIVANJE I DJELATNOST STANICE ZA SAVJETOVANJE PRI IZBORU ZVANJA OD 1931. DO 1948. GODINE - POČETAK PRIMIJENJENE PSIHOLOGIJE U HRVATSKOJ
}

\author{
Ivana Žebec Šilj \\ Institut društvenih znanosti Ivo Pilar \\ Marulićev trg 19, 10000 Zagreb \\ ivana.zebec@pilar.hr \\ Mislav Stjepan Žebec \\ Hrvatski studiji, Odsjek za psihologiju \\ Borongajska cesta 83d, 10000 Zagreb \\ mzebec@hrstud.hr
}

\begin{abstract}
Sažetak
Stanica za savjetovanje pri izboru zvanja osnovana je 19. lipnja 1931. odlukom Izvršnog odbora Zavoda za unapređivanje obrta Komore za trgovinu, obrt i industriju u Zagrebu. Glavna joj je zadaća bila savjetovanje mladih pri izboru obrtničkih ili trgovačkih zanimanja kao i pri izboru stručne škole, a na osnovi liječničkog pregleda tjelesne razvijenosti i zdravlja te psihologijskog testiranja sposobnosti i sklonosti. Osnutak Stanice za savjetovanje pri izboru zvanja može se smatrati početkom razvoja primijenjene psihologije u Hrvatskoj.

Tijekom 17 godina djelovanja Stanicu (kasnije preimenovanu u Zavod) posjetilo je preko 30.000, a psihološki je testirano oko 20.000 osoba. Iako se posljednjih godina djelovanja Stanice/Zavoda broj ispitanih drastično povećao, Zavod je ugašen, dok je psihotehnika (prevladavajuća djelatnost Zavoda) izbačena iz nastavnog programa Psihološkog instituta Sveučilišta u Zagrebu.
\end{abstract}

Ključne riječi: Trgovinsko-industrijska komora, Stanica za savjetovanje pri izboru zvanja, Zavod za savjetovanje u izboru zvanja, Zavod za psihologiju i fiziologiju rada, psihotehnika (primijenjena psihologija), Hrvatski Radiša

I.

Povodom stote obljetnice Kraljevine Belgije od 3. svibnja do 3. studenog 1930. godine, u Liègeu je održana međunarodna izložba pod nazivom Exposition internationale de la grande industrie, sciences et applications, art wallon ancien (Međunarodna izložba industrije, znanosti, primjena i drevne valonske umjetnosti). Ova 
je izložba, prema riječima generalnog ravnatelja Georgesa Moresséea, bila prva takva međunarodna izložba znanosti i nastave. Glavni dio programa obuhvaćao je izložbe o industriji, znanosti, poljoprivredi i socijalnoj ekonomiji. Upravo posljednje imalo je za cilj prikazati stanje u području radničkog stanovanja, slobodnog vremena radništva, tehničkog i strukovnog obrazovanja, industrijske higijene, zaštite maloljetnika (maloljetnih radnika), obiteljskog obrazovanja, itd., a što je provedeno u suradnji s Međunarodnim uredom za zapošljavanje. Paralelno s izložbom također, održane su sjednice stručnih organizacija te međunarodni kongresi, među kojima i Međunarodni kongres za (psiho)tehničku nastavu (Comité français des expositions, 1930).

Naime, primijenjena psihologija ili, kako se u tom razdoblju zvala, psihotehnika, već na prijelazu iz 19. u 20. stoljeće bila je integrativni dio "znanosti o radu", pogotovo onog područja koji se odnosio na profesionalnu orijentaciju. Velika gospodarska kriza 1930-ih, a pogotovo njezine posljedice - smanjenje broja radnih mjesta i nezaposlenost, bili su izazov, ali i poticajni razvojni impuls ovoj "socijalnoj tehnici" kako bi se što učinkovitije npr. pomoglo u borbi protiv nezaposlenosti, koji tada postaje alarmantan problem gotovo svih nacionalnih gospodarstava (Martin, 2013).

Komora za trgovinu, obrt i industriju u Zagrebu kao strukovna organizacija koja zastupa interese različitih gospodarskih subjekata na komorskom području također je sudjelovala na spomenutoj izložbi u Liègeu. Nije poznato je li Kraljevina Jugoslavija imala i svoj paviljon, ali svakako je poznato da je tajnik zagrebačke Komore za trgovinu, obrt i industriju Miroslav Festetić ${ }^{1}$ prisustvovao Međunarodnom kongresu za tehničku nastavu koji se održao od 1. do 5. kolovoza 1930. u sklopu međunarodne izložbe. Valja napomenuti i to da je Komora redovito financirala posjete takvim manifestacijama, koje su bile ne samo prigoda da se predstavi nacionalno gospodarstvo nego i mjesto susreta s inovativnim idejama, tehnikom i razmjene znanja.

Potaknut zaključcima kongresa ${ }^{2} \mathrm{M}$. Festetić po povratku u Zagreb predstavlja ideju o osnivanju Stanice za savjetovanje pri izboru zvanja prvo određenom krugu

1 Miroslav Festetić (Osijek, 1884.-?), pravnik i gospodarstvenik. Poslije Prvog svjetskog rata djeluje u Trgovačko-obrtničkoj komori u Zagrebu, gdje je od 1930. tajnik zadužen za informativnu službu, izložbe, gospodarsku statistiku i obrte. Od 1931. do 1933. upravitelj je Zavoda za unapređivanje obrta. Jedan je od glavnih zagovornika osnivanju Stanice za savjetovanje pri izboru zvanja. (Šugar, 1998)

2 Prva točka Rezolucije kongresa glasi: „Osnutak ureda, odnosno stanica za savjetovanje kod izbora zvanja treba svagdje forsirati i iste generalizirati. Rad ovakovih stanica treba da se temelji na znanstveno utvrđenoj primjeni psihologije, tj. na psihotehnici, proučavajući karakter djeteta, a uz to treba da uzima obzir i na potrebe društva. Naukovanje djeteta, odnosno izbor njegova zvanja treba da je baziran na rezultatima istraživanja ureda, odnosno stanica za savjetovanje kod izbora zvanja." (Trgovinsko-industrijska komora u Zagrebu, 1933, 1). 
zainteresiranih ljudi, među kojima su se bili Aurel Forenbacher ${ }^{3}$ i Ramiro Bujas. Formalna inicijativa o osnivanju stanice nalazi se u Pravilniku Zavoda za unapređivanje obrta Komore za trgovinu, obrt i industriju (Pravilnik je donesen 12. prosinca 1930.). U Članku 2. tog Pravilnika stoji da je zadatak Zavoda "da savjetuje mladićima kod izbora zvanja, ispitujući njihovu fizičku, psihičku i tehničku sposobnost i tako spriječi da ne dođu u pojedina zanatska zvanja mladići, koji nemaju za to fizičkih i psihičkih preduvjeta" (Šešo, 2000, 179). Kako bi se što bolje pripremilo tlo za osnivanje Stanice i prikupile potrebne informacije o praktičnom radu stanice za savjetovanje (u Kraljevini Jugoslaviji tada još nije bilo slične organizacije), Predsjedništvo Zavoda na prijedlog Izvršnog odbora uputilo je A. Forenbachera na studijsko putovanje u München, Berlin, Prag i Beč, gdje je posjetio ondašnje stanice za savjetovanje pri izboru u zvanja (2.-14. travnja 1931.).

$\mathrm{Na}$ temelju Forenbacherova izvještaja o studijskom boravku u inozemnim savjetovalištima 10. lipnja 1931. održana je i Anketa oko osnivanja Stanice u Komori za trgovinu, obrt i industriju u Zagrebu. Na Anketu su bile pozvane sve gospodarske komore i organizacije, obrazovne institucije, te istaknuti pojedinci i pedagoški stručnjaci, kako bi se zainteresiranoj javnosti predstavio projekt i na svojevrstan način ispitalo "javno mnijenje" o potrebi za jednom takvom ustanovom. Prisutni su raspravljali o svim pitanjima buduće Stanice, a pogotovo o suradnji upravnih, školskih, zdravstvenih i obrtnih institucija, kao i gospodarskih subjekata i organizacija. Adolf $\mathrm{Cuvaj}^{4}$, generalni tajnik Komore, zaključio je Anketu riječima "da u Zagrebu postoji veliki interes za osnutak Stanice i da potrebu njena osnutka osjećaju živo poslodavci" (Trgovinsko-industrijska komora u Zagrebu /TIKZ/, 1933, 4). Međutim, bitno pitanje, ono financiranja rada Stanice još uvijek nije bilo riješeno. Konačni poticaj za osnivanje Stanice bilo je predavanje Josipa Matessa ${ }^{5}$ o psihoteh-

3 Aurel Forenbacher (Zagreb, 1882. - Zagreb, 1972.), botaničar i liječnik. Od 1930. zaposlen je na mjestu ravnatelja Državne obrtničke škole te je vanjski konzulent (savjetnik) Trgovinsko-industrijske komore. Jedan je od inicijatora za osnivanje Stanice za savjetovanje pri izboru zvanja i njezin dugogodišnji liječnik, savjetnik i voditelj. Nakon Drugog svjetskog rata radi kao liječnik, internist u Zavodu za socijalno osiguranje u Zagrebu. (Dugački, 1973; Šugar, 1998).

4 Adolf Cuvaj (Zagreb, 1882. - Zagreb, 1974.), ekonomist i pravnik. Glavni je tajnik Trgovačko-obrtničke komore u Zagrebu od 1923. te je bio zadužen za reorganizaciju ove ustanove po ugledu na strane komore. Pokrenuo je i uređivao mjesečnik Privredu, službeni glasnik Komore, a uređivao je i godišnje izvještaje o radu Komore, koji su i danas nezaobilazni izvor podataka o stanju gospodarstva u međuratnom razdoblju (Stipčević, 1989).

5 Josip Matess (?, 1878. - Zagreb, 1936.), strojarski inženjer, viši savjetnik Državnih željeznica, i univerzitetski docent u Zagrebu. Bio je aktivan u Hrvatskom Radiši, posebice kao savjetnik za pitanje izbora zvanja Radišinih pitomaca. U Stanici za savjetovanje pri izboru zvanja bio je suradnik pri konstrukciji pomagala $\mathrm{i}$ aparata, izradi statističkih pregleda i evidencija savjetovanih te promociji rada Stanice i održavanju veza sa različitim gospodarskim organizacijama. (Kolar, 2004; TIKZ, 1934) 
nici održano 18. lipnja 1931. u Hrvatskom Radiši, na koje su bili pozvani predstavnici Komore i Zavoda za unapređivanje obrta. Na tom je predavanju među ostalim iznesena namjera Hrvatskog Radišs ${ }^{6}$ da osnuje Stanicu za savjetovanje pri izboru zvanja. U raspravi koja je uslijedila nakon predavanja prevladalo je mišljenje "da je Komora, odnosno Zavod za unapređivanje obrta najpodesnija ustanova za osnutak Stanice" (TIKZ, 1933, 4).

U trenutku kada se raspravljalo o osnivanju Stanice svijet je već duboko potresala velika gospodarska kriza. U Hrvatskoj, odnosno Kraljevini Jugoslaviji, ona još nije dobila pravi zamah (nastupit će u jesen 1931. slomom privatnog bankarstva), međutim s obzirom na orijentaciju Jugoslavije na primarnu proizvodnju i ekonomsku strukturu stanovništva, u kojem prevladava poljoprivredno stanovništvo, već agrarna kriza iz 1926. rezultirala je iznimno visokom nezaposlenosti u Hrvatskoj (registriranom i prikrivenom), tako da je 1928. nezaposlenih u dobi od 15 do 54 godine bilo 25,5\%, a 1932. Njihov udio se popeo na 27,0\%. (Stipetić, 2012). Očigledno svjesni ove situacije, ali i problema koji proizlaze iz nedovoljnog broja stručnog, kvalificiranog radništva u privrednim zanimanjima Izvršni odbor Zavoda za unapređivanje obrta 19. lipnja 1931. donio je zaključak "da se privede u život Stanica za savjetovanje kod izbora zvanja" (TIKZ, 1933, 4).

A. Forenbacher, ravnatelj Državne obrtne škole za potrebe rada Stanice ustupio je dvije prostorije u školi u kojima je bila uređena liječnička ambulanta i laboratorij za psihologijsko ispitivanje (odobreno i od strane Ministarstva trgovine i industrije), dok je velika zasluga R. Bujasa u priređivanju nacrta Pravilnika Stanice (vidjeti Pri$\log 1$ ), čiju je konačnu redakturu potvrdio Upravni odbor Zavoda za unapređivanje obrta 27. kolovoza 1931.

Na javnom natječaju predsjedništvo Komore izabralo je A. Forenbachera za liječnika i savjetnika koji je sukladno članku 9. Pravilnika ujedno obnašao i dužnost šefa Stanice. Isto tako javnim natječajem mjesto psihotehničara (psihologa) Stanice dobio je Zlatko Pregrad ${ }^{7}$, profesor Državne ženske učiteljske škole.

Za početak rada, Komora je odobrila Stanici kredit, a i Ministarstvo trgovine i industrije pripomoglo je određenim sredstvima kojima su uređene prostorije u Dr-

6 Hrvatski Radiša osnovan je 1903. kao Društvo za namještanje naučnika u obrt i trgovinu, a od 1916. djeluje pod nazivom Hrvatski Radiša. Društvo se brinulo za nadarenu i siromašnu djecu te ih je slalo na nauk kako bi postali obrtnici, a time i posredno transformirali obrt u modernu gospodarsku granu, koja će se upotpunjavati s industrijom (Kolar 2004).

7 Zlatko Pregrad (Samobor, 1903.- Zagreb, 1983), pedagog i psihotehničar (psiholog). Od 1932. djeluje kao prvi psiholog (psihotehničar) u Stanici za savjetovanje pri izboru zvanja, gdje surađuje sa (i hospitira u) institucijama za profesionalnu orijentaciju u inozemstvu i u Kraljevini Jugoslaviji. Od 1940. izvanredni je profesor pedagoške grupe predmeta na Akademiji likovnih umjetnosti, a od 1949. na Pedagoškom institutu Filozofskog fakulteta u Zagrebu (Vukasović, 2015). 


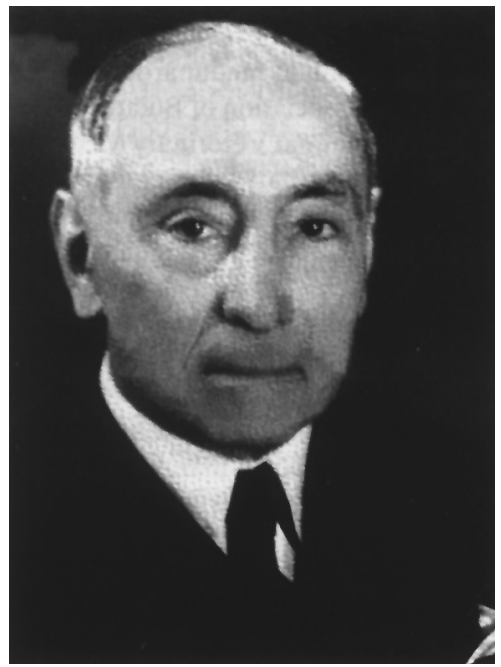

Dr. Aurel Forenbacher (1872.-1972.)

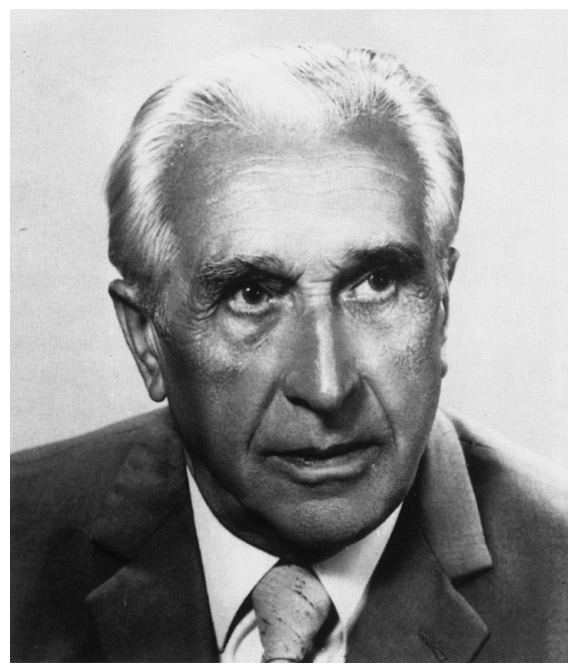

Prof. Zlatko Pregrad (1903.-1983.)

žavnoj obrtnoj školi i nabavljeni instrumenti za liječničku ambulantu od zagrebačkih tvrtki. Aparati i instrumenti za psihološka ispitivanja, međutim, nabavljeni su od njemačke tvrtke H. Diel iz Leipziga. ${ }^{8}$ Konačno, početak rada Stanice oglašen je i u dnevnim novinama i glasilima, a svoja vrata otvorila je 2. siječnja 1932. godine.

Stanica do 1933. godine djeluje u okviru Zavoda za unapređivanje obrta Komore za trgovinu, obrt i industriju, no kada je u travnju 1933. došlo do diobe na Trgovinsko-industrijsku i Zanatsku komoru, Zavod je ukinut, a Stanica dolazi pod okrilje Trgovinsko-industrijske komore (TIKZ). Tom je prilikom u manjoj mjeri promijenjen i Pravilnik Stanice, sadržajno se mijenjaju članak 1, 9 i 24 (u novom Pravilniku 22.), dok su članci 10 i 16 ukinuti. Uredbom Ministarstva trgovine i industrije od 3. prosinca 1938. TIKZ ponovno je podijeljena na zasebne Trgovinsku komoru i Industrijsku komoru, pri čemu Stanica za savjetovanje o izboru zvanja dolazi pod upravu Trgovinske komore, ali je osnovan poseban Odbor "sa zadaćom da brine za materijalna sredstva potrebita za uzdržavanje Stanice" u kojem su bili, osim Trgovinske, i Industrijska komora, zatim Banska Uprava Savske banovine, Poglavarstvo grada Zagreba i Javna burza rada (Trgovinska komora u Zagrebu / TKZ/, 1940, 1).

8 Spomenuta tvrtka iz Leipziga proizvodila je i instrumente koje je konstruirao R. Bujas, poput estaziometra na vlas, kamatometra i batića za patelarni refleks (Pavlina, Kolesarić, 1987). 


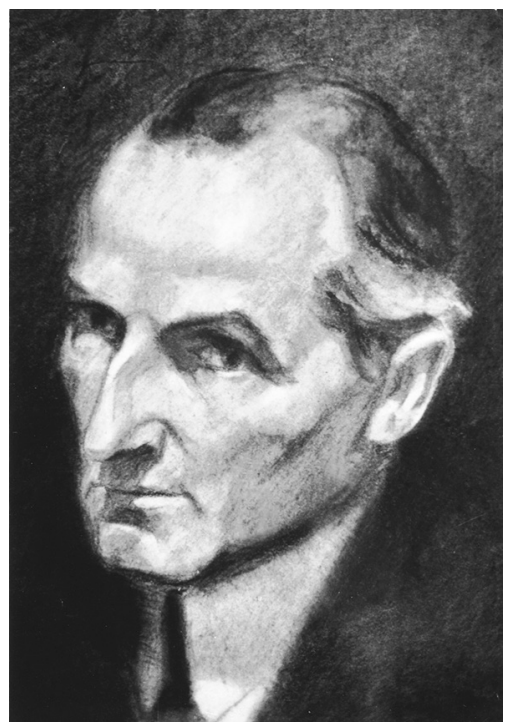

Dr. Ramiro Bujas

(1879.-1959.)

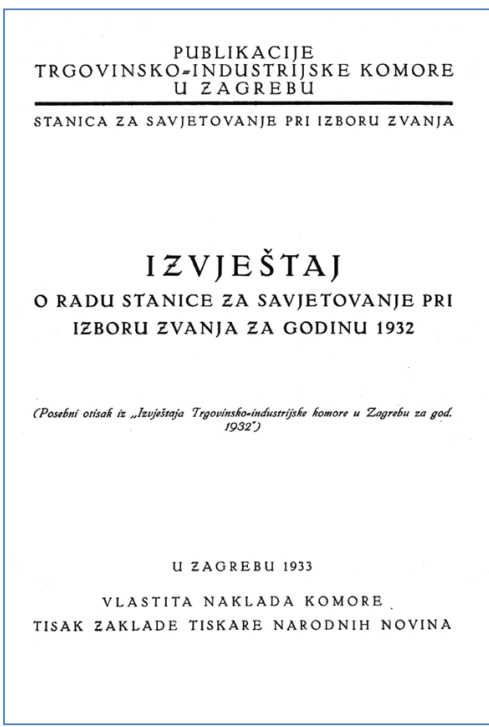

Godišnji izvještaj o radu Stanice

Tijekom 1932. Stanica je bila smještena kako je već spomenuto u Državnoj obrtničkoj školi, ali već početkom 1933. (27. siječnja) ustupljene su joj prostorije u uredskoj zgradi TIKZ na tadašnjem Wilsonovu (današnjem Roosveltovu) trgu, gdje je djelovala sve do izgradnje nove zgrade Javne burze rada 1937. godine. Na novoj adresi (Zvonimirova 15) Stanica je imala na raspolaganju cijeli treći kat s deset prostorija i velikom dvoranom za skupna ispitivanja (TIKZ, 1934; Barić i Šešo, 2008). Početkom 1940. godine Stanica je bila primorana premjestiti se iz prostorija zgrade Javne burze rada na Trg Petra I. osloboditelja 17 (današnjem Trgu žrtava fašizma), gdje je djelovala sve do kraja Drugog svjetskog rata (Forenbacher, 1943).

Stanica za vrijeme Drugog svjetskog rata i dalje je u sklopu Trgovinske komore, no mijenja naziv u Zavod za savjetovanje pri izboru zvanja 1942. godine, čiji je zadatak utvrđivanje sposobnosti naučnika za stupanje u nauk (Zakonska odredba o naučnicima i mladim radnicima i namještenicima, 1942). Budući da su Zakonskom odredbom o komorama i stručnim zajednicama (20. travnja 1942.) te Naredbom o ustrojstvu i djelokrugu predstavništava hrvatskih privrednih komora (15. srpnja 1942.) osnovane četiri komore na razini države, djelokrug Zavoda tada se proširuje na područje cijele NDH, a ne više samo grada Zagreba, odnosno bivšeg komorskog područja (Kolar, 2002). Od 1944. godine Zavod za savjetovanje pri izboru zvanja izdvojen je iz Trgovinske komore i prelazi u nadležnost Glavne uprave posredovanja rada. Kako je ovo razdoblje djelovanja Stanice/Zavoda potpuno neistraženo i u 
literaturi se gotovo ne spominje, svakako je vrlo bitno da se na temelju arhivskog gradiva iz fonda Zavoda za psihologiju i fiziologiju rada, koji se čuvaju u Državnom arhivu u Zagrebu (HR-DAZG-239 Zavod za psihologiju i fiziologiju rada), rekonstruira njezino djelovanje, pogotovo stoga što se njezin teritorijalni djelokrug bitno proširio. Isto tako tim istraživanjem moguće je dobiti uvid u različite strukture (socio-ekonomsku, fizičku/antropometrijsku i psihološku) mlađeg kontingenta radno-sposobnog stanovništva za vrijeme Drugog svjetskog rata.

II.

Usluge Stanice za savjetovanje pri izboru zvanja bile su uglavnom namijenjene mladim osobama koji su stupali u tzv. "privredna" zvanja, premda su savjete tražili i oni koji su se namjeravali dalje akademski školovati. Također, Stanica je povremeno pružala savjete i odraslim nezaposlenim osobama, mladeži koje nije sposobna za "privređivanje" kao i ženama koje su "posrnule" (TIKZ, 1933, 8). Stanoviti postotak posjetitelja i korisnika usluga Stanice bili su i učenici nižih i srednjih škola. Stanica je početkom svoga rada proslijedila obavijest o svom radu svim zagrebač-

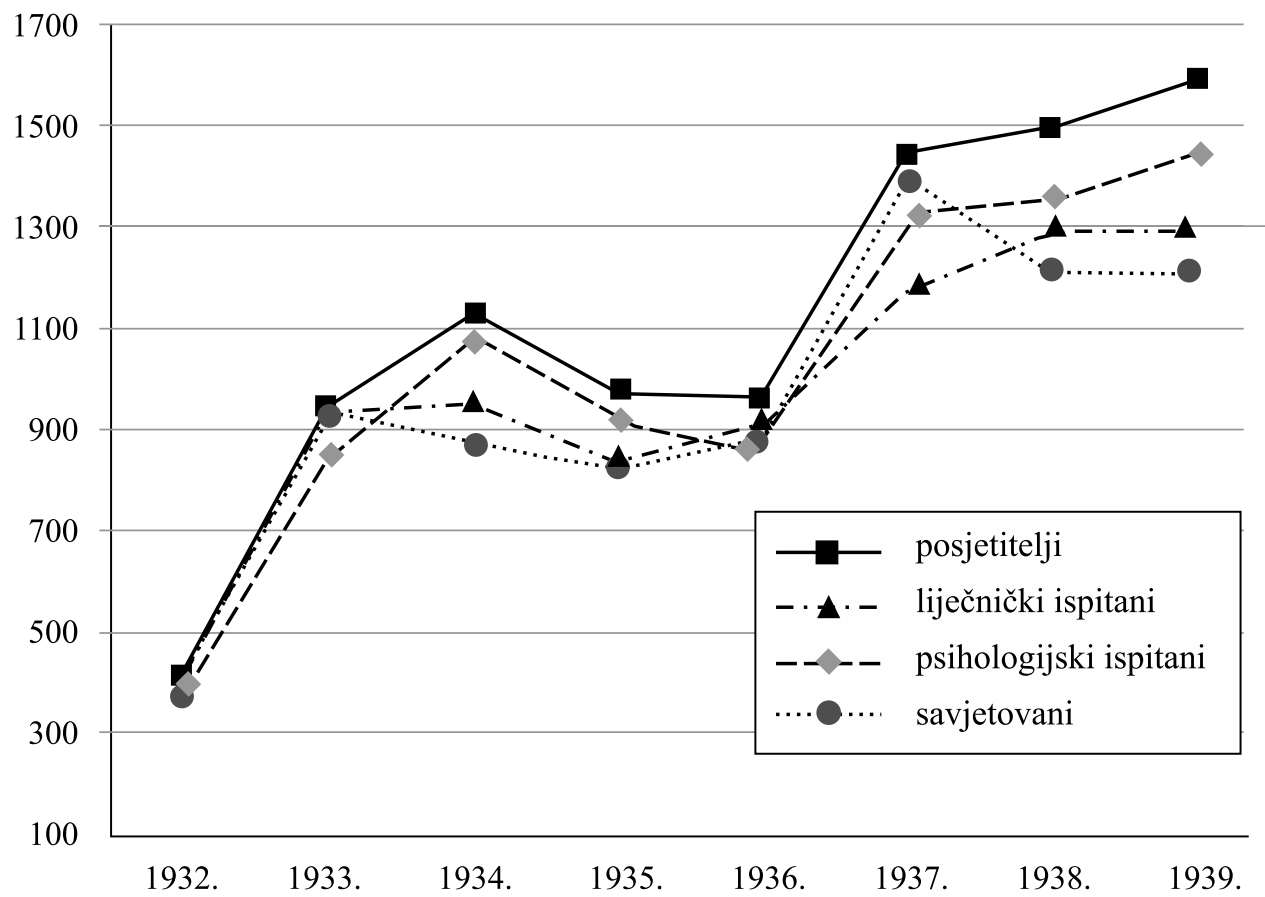

Slika 1. Trendovi promjene broja posjetitelja, liječnički ispitanih, psihologijski ispitanih i savjetovanih osoba u Stanici za savjetovanje pri izboru zvanja od 1932. do 1939. godine. 
kim školama, a tom prilikom bile su dostavljene školama i Učeničke karte kako bi se dobili što vjerodostojniji podaci o fizičkom stanju i psihičkim karakteristikama učenika od strane školskog liječnika i nastavnika (TIKZ, 1933). Međutim, uslugama Stanice najviše su se koristili pitomci Hrvatskog Radiše, koje je ova organizacija sustavno od 1919. namještala u različita privredna, pogotovo obrtnička i trgovačka zvanja (Kolar, 2004; Matešić, 2017).

Kako bi se zorno stekao dojam o intenzitetu razvoja djelatnosti Stanice u prvim godinama njena rada, grafički su prikazani trendovi promjene broja posjetitelja, liječnički ispitanih, psihologijski ispitanih i savjetovanih osoba u Stanici.

Iz Slike 1 razvidno je kako je nakon snažnog razvoja djelatnosti Stanice u njene prve tri godine rada, došlo do dvogodišnje stagnacije (pa čak i pada), a potom ponovno do značajnijeg rasta od 1937. do 1939. U tom smislu bit će zanimljivo u daljnjim istraživanjima pronaći objašnjenje za navedenu stagnaciju, ali i za smanjenje broja savjetovanih osoba (u odnosu na broj ispitanih) u zadnje dvije promatrane godine.

Poznato je da radna uspješnost ovisi o više čimbenika, kao što su specifična znanja i vještine, opće i specifične sposobnosti, motivacija za posao, uvjeti na radu, uvjeti života, te prilike u obitelji, dok "sa zdravstveno-psihološkog stajališta, radna sposobnost ovisi o stanju zdravlja, usklađivanju zdravstvenih i psihičkih kapaciteta radnika sa zahtjevima posla te o motivaciji za rad" (Šarić i Šarić, 2002, 297). Isto tako, rad, kao i radni uvjeti mogu pogoršati već postojeći zdravstveni problem, ali i postojeće životne navike također mogu zajedno s uvjetima rada dovesti do razvoja bolesti (Žuškin i sur., 2006). Stoga je u čl. 5. Pravilnika Stanice naglašeno da "kod savjetovanja pri izboru zvanja valja u prvom redu utvrditi sposobnost u tjelesnom, psihičkom [...] pogledu" (TIKZ, 1933, 5).

Liječnički pregled u Stanici imao je "svrhu da poda jasnu sliku o zdravstvenom stanju pregledanog lica, ali i da pruži prognostičke podatke, ako bi se ispitanik odlučio za izvjesno zvanje" (TIKZ, 1937, 7). Liječnički pregled u Stanici obuhvaćao je utvrđivanje trenutačnog zdravstvenog stanja (status praesens) ispitanika kao i bilježenje osobne te obiteljske anamneze. U slučaju potrebe ispitanici su bili upućeni i na detaljniju obradu i različite specijalističke preglede u Sveučilišnu kliniku u Zagrebu te Antituberkulozni institut i dispanzer.

Uvidom u podatke o trenutačnom zdravstvenom stanju, odnosno uočenim patološkim nalazima kod djece i mladeži može se zaključiti da su najučestaliji bili manji zdravstveni problemi kao što su karijes, kronične upale krajnika, pjegavost, ravna stopala, kratkovidnost i sljepoća za boje, te svrab i gušavost. Međutim, pored spomenutih nalaza, znakovito je da je kod oko 5-10\% pregledanih ispitanika bio ustanovljen i loš opći razvoj, odnosno stanje izgladnjelosti (inanitia). Usporedbe radi, rezultati sistematskih pregleda u školskom ambulatoriju u Zagrebu, u razdoblju od 1924. do 1940. godine upućivali su na to da je osnovna problematika "u odnosu na zdravlje učenika bila vezana uz zarazne bolesti, rahitis, adenoidne vegetacije (treća mandula/krajnik), strumu (gušavost/povećanje štitne žlijezde) i nedovoljnu ishra- 
njenost” (Hofgräff, Fatović-Ferenčić, 2012, 18). Za razliku od trenutačnog stanja ispitanika podaci prikupljeni iz osobne i obiteljske anamneze upućuju na vrlo raširenu pojavu obolijevanja odnosno smrtnosti uzrokovane tuberkulozom. Tuberkuloza je prema statističkim pokazateljima za Kraljevinu SHS/Jugoslaviju po smrtnosti bila na vodećem mjestu tijekom međuratnog razdoblja (Dugac, 2005).

Budućom obradom podataka prikupljenim od strane liječnika Stanice, a čuvaju se u Državnom arhivu u Zagrebu u sklopu spomenutog fonda Zavoda za psihologiju i fiziologiju rada, moguće je osim medicinske slike dobiti i svojevrstan socijalni presjek korisnika/posjetitelja Stanice jer dostupni izvori (pogotovo iz obiteljske anamneze) daju podatke i o socijalnom statusu ispitanika.

Psihotehnička ispitivanja provela su se na oko $92 \%$ posjetitelja Stanice. Ako je već na liječničkom pregledu ustanovljeno da ispitanik nije sposoban za "ulazak u privredno zvanje", psihotehničko ispitivanje je izostalo. Isto tako, za niže kvalificirana zvanja također nije bilo potrebno obavljati ispitivanje, premda se u prvim godinama i nad takvima vršilo ispitivanje "da se kod što većeg broja psihologijskih metoda dobije rezultati za naše prilike i da se tako ove metode verificiraju" (TIKZ, 1933, 18). U psihotehničkom odjeljenju Stanice koristile su se metode za koje se smatralo "da će biti za naše prilike najpodesnije" (TIKZ, 1933, 18). Osnova radu bili su psihogrami ili psihologijski profili raznovrsnih zvanja - opisi pojedinih zvanja koja izlažu načine rada i sposobnosti koja su za tu vrstu rada potrebna, odnosno sadrže "kritičke prikaze pojedinih zvanja te egzaktne psihologijske metode rada kojima se omogućuje konstatacija pojedinih psihičkih sposobnosti te uopće psihičkog profila ili strukture pojedinca. ${ }^{10}$... Obzirom na ove profile istražuju se psihotehničkim metodama sposobnosti pojedinca da se konstatira da li njegove individualne sposobnosti odgovaraju sposobnostima potrebnim u odabranom zvanju." (TIKZ, 1933, 18-20). Radilo se o metodama "kojima se konstatira općeniti razvoj (Binet-Simon, Jaederholm - Termann) do onih kojima se dolazi do uvida u potpuno specijalne sposobnosti (aparati za ispitivanje rada objema rukama ili za ispitivanje stanovite vrste pažnje)" (TIKZ, 1933, 18-19.). U slučaju da su sposobnosti ispitanika odgovarale potrebnim za odabrano zanimanje psihotehničko ispitivanje je završavalo, a ako nije, ispitivanje se nastavljalo i "traži se njegov cijeli psihologijski profil, uvid u sve njegove sposobnosti i njegovu psihičku strukturu uopće pa se onda s obzirom na taj nalaz traži profil zvanja" (TIKZ, 1933, 20). Dakle, ispitivanje se provodilo od jedan do četiri puta ovisno o kakvom se zanimanju kandidat namje-

9 Ova konstatacija vrlo je bitna zato što se može dobiti diferencirana slika koje metode su bile primjerene domaćim prilikama, odnosno koje su točno „domaće prilike“ utjecale na odabir metode.

10 Referentna literatura za izradu psihograma bile su publikacije Zemaljskog radnog ureda Sachsen-Anhalt, Handbuch der Berufe, Magdeburg-Leipzig, 1927. (i dalje) (TIKZ, 1933). 
ravao posvetiti (Čepulić, 1938). Ti navodi upućuju kako se u Stanici vrlo sustavno pristupalo dijagnosticiranju pojedinčevih radnih sposobnosti, a temeljem toga i pripadnoj profesionalnoj orijentaciji. Štoviše, korišteni otvoreni postupci kojima se dopuštalo da savjet o izboru adekvatnog zvanja završi tek nakon višekratnog testiranja, predstavljaju svojevrstan luksuz i u današnjim okolnostima te sugeriraju kako je psihotehnička djelatnost Stanice imala i znanstvenu dimenziju.

Početkom rada Stanice skupna psihologijska ispitivanja provođena su prema metodologijama koja su primjenjivane u Institut für Arbeits und Berufspsychologie Halle a/S i Landesarbeitsamt Bayern in München. "U jednom i drugom sistemu imade postupaka koje je zagrebačka Stanica upotrebljavala već u prvoj godini rada i koji su se već tada pokazali prikladnim za naše prilike. Konačno odabran je münchenski sistem rada koji sadržava 50 raznih testova za skupna ispitivanja, a uređen je od psihologa Alberta Hutha" (TIKZ, 1934, 12). Kod pojedinačnih ispitivanja koristili su se tzv. pokusi rada. "Ispitanik treba ovdje kao i u zvanju izvršiti stanoviti rad koji je stvaranjem prirodnih i jednostavnih okolnosti srodan radu koji se vrši u stvarnom djelovanju, zbog čega nestaje ona zbunjenost koja katkad kod ispitivanja nastupa" (TIKZ, 1934, 12-13). Navedene metode ispitivanja, odnosno testovi koji su se koristili nad ispitanicima - kao što su Bobertagova adaptacija Binet-Simonova testa, Stejskalova adaptacija Binet-Simonove ljestvice, koje je priredio Z. Pregrad 1933. i 1935. godine, te prerada Vojnog alfa i Vojnog beta testa, koje su adaptirali R. Bujas i Z. Pregrad zajedno sa psihologom Centralnog higijenskog zavoda u Beogradu, Maksimom Agapovim 1935. odnosno 1937. godine - koristile su se uglavnom na osobama koje su išle u obrtnička zanimanja (Matešić, 2011). No, psihotehničko odjeljenje 1938. odlučuje "pripremiti metode koje će omogućiti djelovanje Stanice na području industrijskih potreba i industrijske selekcije radne snage. Ove su potrebe u toku ove godine (1938.) došle konkretno do izražaja slanjem radnika u Stanicu u svrhu selekcije za stanovite tvorničke vrste rada... U tu je svrhu pripremljena za štampu metoda ustanovljivanja inteligencije odraslih nepismenih ili manje pismenih te izbor pomagala potrebnih u svrhe selekcije radne snage..." (TKZ, 1939, 13).

Iako je djelatnost Stanice uglavnom bila usmjerena na profesionalnu orijentaciju mladih koji su se izravno obraćali (ili bili upućeni) Stanici, bilo je i slučajeva kada se u istraživačke svrhe provodilo ispitivanje učenika ili kada se od Stanice tražilo da provede selekcijski postupak među prijavljenim kandidatima određenih organizacija i poduzeća. Tako je u kolovozu 1933. Stanici povjeren zadatak odabira 15 stipendista Hrvatskog Radiše za daljnje školovanje u građanskoj školi, odnosno kasnije naukovanje za različite obrte. Više od 40 kandidata podvrgnuti su skupnom ispitivanju sposobnosti shvaćanja, pažnje, pamćenja, fantazije, logičkog mišljenja, matematičkog mišljenja, tehničkog mišljenja, načina rada te su prema razvoju tih sposobnosti i rangirani. Bila je to, prema riječima sastavljača godišnjeg izvještaja o radu Stanice, "prva selekcija u našoj sredini provedena psihotehničkim metodama" (TIKZ, 1934, 16). Godinu dana kasnije, 1934. Upravno vijeće Gradskih poduzeća raspisalo je natječaj za elektrotehničke i strojobravarske naučnike-pitomce koje će 
poslati na usavršavanje u Čehoslovačku i Austriju. Budući da su se na natječaj javila 162 kandidata, Stanica je provela izbor najboljih kandidata za spomenuta zvanja. Pored liječničkog pregleda kojim se ustanovila fizička sposobnost za navedena zanimanja, provedeno je skupno ispitivanje opće nadarenosti i specijalnih sposobnosti za zvanje elektrotehničara i strojobravara (shvaćanje, pažnja, asocijacija, fantazija, logičko, tehničko i matematičko mišljenje, način rada i tempo rada). Na temelju prvog kruga ispitivanja izdvojena je trećina kandidata s najboljim rezultatima te je nad njima proveden daljnji postupak selekcije koji je obuhvaćao skupno ispitivanje opće sposobnosti i specijalne sposobnosti (tehnička kreativnost i tehničko konstruktivno mišljenje) te pojedinačna ispitivanja sposobnosti manualnog rada (spretnost ruke, sigurnost ruke, spretnost prstiju, opip, način rada i brižljivost rada). S obzirom na rezultate drugog kruga selekcije napravljena je konačna rang lista od 53 kandidata (TIKZ, 1935).

Kako bi se provjerile mogućnosti primjene i upotrebljivost stanovitih metoda (testova) za "našu sredinu" na većem broju ispitanika koncem 1934. godine Stanica je uputila Prosvjetnom odjeljenju Banske uprave zahtjev da se omogući ispitivanje psihičkih osobina mladića u školama (TIKZ, 1935, 9). Ispitivanje je provedeno 1935. godine na 647 mladića, polaznika srednjih i građanskih škola u Zagrebu, Krapini, Varaždinu, Virju, Brodu n/S, Vinkovcima, Ogulinu, Sušaku, Senju, u Krku, Gospiću i Bjelovaru (TIKZ, 1936). Slično ispitivanje provedeno je i 1938. godine nad 123 gimnazijska maturanta u Zagrebu i Vinkovcima te 393 polaznika 3. i 4. razreda građanskih škola u Zagrebu. Maturanti su testirani Vojnom alfa serijom, dok se nad polaznicima građanske škole provodio test "tehničke sposobnosti" (TKZ, 1939). Osim ovog testiranja polaznika škole, obavljeno je i testiranje inteligencije manipulativnog činovništva i dnevničara Trgovinsko-industrijske komore 1935. godine kako bi se ispitala primjena Vojnog alfa testa na odraslim osobama (TIKZ, 1936). Tim postupcima Stanica je očito sudjelovala u adaptaciji i izradi normi tadašnjih svjetskih standarda za testiranje inteligencije za hrvatsku populaciju i time pokazala zreo pristup korištenju međunarodnih psihodijagnostičkih sredstava, ali i postavila temelje validiranog psihologijskog testiranja u primijenjene svrhe.

Uz selekcijske postupke i ispitivanja radi provjere svrsishodnosti testova, psiholog Stanice, Z. Pregrad, sudjelovao je i u istraživačkim aktivnostima drugih institucija. Naime, sukladno prirodi svoga posla Stanica je bila upućena na suradnju s nekoliko institucija, uostalom prema čl. 17. Pravilnika bila je dužna surađivati sa Psihologijskim institutom Sveučilišta u Zagrebu. Međutim, to nije bila jedina institucija s kojom je imala razvijene suradničke odnose. Također u svom je radu bila upućena i na Sveučilišnu kliniku te Državni antituberkulozni institut i dispanzer, a suradnja je bila uspostavljena i sa Stanicom za psihohigijenu u Zakladnoj bolnici kao i sa Školom narodnog zdravlja kod Higijenskog zavoda. Upravo je za potrebe istraživanja psihičkog razvoja neselekcioniranog seoskog stanovništva Mraclina i okolnih sela koje je provodila Škola narodnog zdravlja, Z. Pregrad priredio Thompsonovu ili Northumberlansku seriju za ispitivanje intelektualne sposobnosti mladića 
u dobi prijelaza iz osnovne u srednju školu (TIKZ, 1938). Isto tako, sudjelovao je s Centralnim higijenskim zavodom u Beogradu u priređivanju Vojnih alfa testova za provođenje "psihometrijskih ispitivanja i istraživanja psihičkih osobina našeg naroda" (TIKZ, 1935, 17).

Pored Z. Pregrada u Stanici je povremeno surađivao i Zoran Bujas, koji će se nakon hospitacije u pariškom L' Institut national D'orientation profesionelle kod Henria Piérona 1936. zaposliti u Stanici (i raditi tamo sve do njena ukidanja). Sljedeće će godine, zajedno s ocem, objaviti i test za mjerenje inteligencije - 'Seriju Z' - prvo i potpuno originalno djelo domaćih psihologa (Matešić, 2011).

\section{III.}

Imajući u vidu sva ograničenja koje donosi rad u (pred)ratnim okolnostima, Stanica relativno intenzivno i ambiciozno provodi svoje djelatnosti. Budući da je od samog osnutka bila vezana uz Hrvatskog Radišu, tako je i kroz cijeli ratni period, provodila liječničko i psihotehničko ispitivanje Radišinih pitomaca, ali u smanjenom opsegu. Premda je glavna zadaća Radiše bilo smještanje siromašne djece $u$ nauk, za vrijeme rata taj je cilj sve više gubio na prioritetu, a važnost je dobivao "rad na privredno-gospodarskom polju" i humanitarnom zbrinjavanju izbjeglica (Kolar, 2004, 255). Primjerice, već 1942. godine primjetan je pad broja pitomaca koji se pripremaju za nauk - od 824 pozvana, odazvalo se njih 513, da bi broj 1945. iznosio svega 250 mladića (Kolar, 2004). Međutim, broj posjetitelja Stanice, iskazan u osvrtu A. Forenbachera (1943) na jedanaest godina savjetovanja kod izbora zvanja, za godine 1940., 1941., i 1942. pokazuje znatan porast u odnosu na prethodno desetljeće (broj posjetitelja u prosjeku se povećao za 1800).

Povećanje broja posjetitelja Stanice odraz je zajedničkih napora Gradskog zdravstvenog odsjeka (Gradskog fizikata), Okružnog ureda za osiguranje radnika i

Tablica 1. Broj posjetitelja Stanice za savjetovanje pri izboru zvanja 1940.-1942. (ukupno i ovisno o spolu)

\begin{tabular}{lcll}
\hline Godina & Ukupno posjetitelja & Muški & Ženski \\
\hline 1940. & 2028 & 1797 & 231 \\
1941. & 2708 & 2285 & 423 \\
1942. & 2164 & 1784 & 380 \\
$M$ & 2300,0 & 1955,3 & 344,7 \\
$S D$ & 359,82 & 285,57 & 100,76 \\
\hline
\end{tabular}

Izvor: Forenbacher, 1943. 
Stanice za savjetovanje o izboru zvanja oko osnivanja Stanice za socijalnu i zdravstvenu zaštitu naučnika koja je počela s radom u rujnu 1940., a cilj joj je bio reorganizacija i centralizacija skrbi za naučnike na području grada Zagreba. Spomenuta je Stanica izdavala potvrde za sklapanje naučničkog ugovora samo onim naučnicima koji dobili pismeni izvještaj Stanice za savjetovanje pri izboru zvanja da su u fizičkom i psihičkom pogledu sposobni za željena zvanja. Na taj je način Stanica postala nezaobilaznom institucijom u osposobljavanju za različita zvanja u obrtu i trgovini. Pored navedenog povećanja broja posjetitelja, teško je ne primijetiti spolne razlike u broju posjetitelja u razdoblju 1940.-1942. i činjenicu da su ispitivanjima radi profesionalnog savjetovanja u $85 \%$ slučajeva pristupali muškarci. Taj podatak jednim dijelom sigurno odražava patrijarhalno poimanje uloge žene u društvu te strukturu industrijskih i obrtničkih djelatnosti, no buduća istraživanja bi mogla ponuditi i druga objašnjenja. U tom smislu također treba uvažiti i činjenicu da je u navedenom razdoblju broj ženskih posjetitelja stanice dvostruko više varirao od muških (što je vidljivo iz pripadnih koeficijenata varijabilnosti, a nije se provjeravalo F-omjerom zbog međuzavisnosti članova vremenskog niza). Do 1941. usluge Stanice bile su besplatne, no zbog povećanog opsega posla i sve većih troškova, Predsjedništvo Trgovinske komore odlučilo je naplaćivati pristojbe za ispitivanja i savjetovanje, od kojih su bili izuzeti pitomci Hrvatskog Radiše (Forenbacher, 1943).

Važno je istaknuti da od samog početka djelovanja Stanice u godišnjim je izvješćima stalno naglašavana potreba da se zakonski uredi obvezatno ispitivanja tjelesne i psihičke sposobnosti svakog djeteta prije sklapanja naučničkog ugovora na području cijele države, no to joj nije uspjelo u međuratnom razdoblju. Tek za vrijeme Drugog svjetskog rata bilo je određenih pomaka u tom smjeru, barem u zakonodavnom smislu. U kojoj je mjeri ta zadaća stvarno provedena u djelo nije poznato bez daljnjeg istraživanja arhivskog gradiva. Ali, prema Zakonskoj odredbi o naučnicima, mladim radnicima i mladim namještenicima iz 1942. godine "svaki naučnik mora navršiti prije stupanja u naukovanje 14 godina života i da je tjelesno kao i umno sposoban za učenje izabranog zvanja, a o tom daje pismeno mišljenje savjetodavni zavod za izbor zvanja, dok dozvolu izdaje na temelju tog mišljenja Glavna uprava posredovanja rada". Također, ovom se zakonskom odredbom predviđalo da mladi namještenici i naučnici pohađaju stručne škole za vrijeme trajanja naukovanja, "a o tome odlučuje nadležni savjetodavni zavod za izbor zvanja" (Zaštita najmladjih u hrvatskom priradu, 1942, 1).

Vezano za ovu zakonsku odredbu je i rješenje Trgovinske komore doneseno 17. ožujka 1942. da Stanica za savjetovanje o izboru zvanja promijeni naziv u Zavod za savjetovanje u izboru zvanja (Forenbacher, 1943). Također u vezi s tom zakonskom odredbom Trgovinska je komora ponudila da uz odgovarajuću odštetu taj svoj Zavod prepusti državi (Skrb za priradnu i radničku mladež, 1942).

Zavod je osim na uređivanju zakonske obveze ispitivanja fizičke i psihičkih sposobnosti za naučnike, iz godine u godinu urgirao kod različitih instanci da se uvede obveza liječničkog pregleda i ispitivanja psihičkih sposobnosti za osobe koje 
stupaju u prometna zvanja. Iako ne postoje egzaktni podaci u onodobnim objavljenim izvorima koji potvrđuju da je Zavod provodio te djelatnosti, ipak je ulagao napore kako bi upoznali javnost sa psihologijom i psihotehnikom različitih prometnih zanimanja.

Za ovaj period djelovanja Zavoda bitno je naglasiti da su Z. Bujas i Boris Petz (nakon što je diplomirao zaposlen je u Zavodu 1944.) pripremili i nove serije testova za Radišine pitomce - Seriju R (1940.) i R-II (1944.) dok je Z. Bujas samostalno sastavio seriju testova - N-seriju - za ispitivanje inteligencije odraslih nepismenih osoba. Osim toga, Z. Bujas i Adela Ostojčić ${ }^{11}$ priredili su i reviziju Ballardova testa - serija B.O.B (1942.) - za skupno ispitivanje inteligencije školske djece (Matešić, 2006, Petz, 2005).

IV.

U međuratnom razdoblju u Kraljevini Jugoslaviji postojale su tri ustanove za profesionalnu orijentaciju, - u Beogradu, Ljubljani i Zagrebu - zagrebačka je bila jedina koja je preživjela rat. Nakon 1945. godine ušla je u sastav Ministarstva rada NR Hrvatske kao Zavod za psihologiju i fiziologiju rada. S obzirom na krupne društveno-ekonomske promjene i Zavod je morao proći kroz temeljite promjene. Stoga je rad organiziran u tri odsjeka; odsjek za raspodjelu stručnih kadrova i radnu pedagogiju, odsjek za racionalnu organizaciju rada s psihofiziološkog stajališta i odsjek za suzbijanje profesionalnih nesreća. Pored redovitih aktivnosti u obliku ispitivanja mladih, Zavod je provodio i testiranje sposobnosti kandidata za prometna zvanja, ispitivanje djece sa smanjenim psihičkim i fizičkim sposobnostima i selekcije za različite stručne škole. Tijekom 1948. godine kada je rad Zavoda naprasno ukinut odlukom Ministarstva rada NR Hrvatske, broj ispitanih i savjetovanih osoba dosegao je rekordnu brojku od 5000, a zapošljavao je jednog liječnika i pet psihologa (Bujas, 1952).

Uzroke zabrani rada Zavoda u trenutku kad Jugoslavija započinje intenzivnu industrijalizaciju moguće je povezati s odlukom CK SKP(b) (Centralni komitet Svesavezne komunističke partije (boljševika)) od 4. lipnja 1936. u kojoj su osuđene psihotehničke metode kao neznanstvene i antimarksističke (Matešić, 2010). Osnovni prigovor metodi testova i psihotehnici bio je "da se na osnovu rezultata u

11 Adela Ostojčić-Bujas (Podvinje, 1908.- Zagreb, 2006.), psihologinja. Nakon diplome iz psihologije i pedagogije na Filozofskom fakultetu u Zagrebu, provela je dvije godine na studiju u Parizu. Asistentica je R. Bujasa na Psihologijskom institutu do 1949., a od 1950. profesorica je psihologije na Pedagoškoj akademiji. Zajedno s Z. Bujasom objavila je radove iz područja ispitivanja inteligencije i psihofiziologije osjeta (Težak, Markovac, 1971). 
testu neopravdano pretpostavlja da će trenutno uspostavljena razina biti i unaprijed karakteristična za ispitanika”. Drugi prigovor je da se pri postavljanju dijagnoze na osnovi testa "ne vodi računa o dosadašnjem procesu razvoja ispitanika", dok je treći prigovor, odnosno zamjerka metodi testova "da se norme dobivene na ispitanicima određene klasne sredine uzimaju kao kriterij prema kojem se vrednuju sposobnosti i drugih ispitanika, koji su se razvijali u drugim uvjetima". Četvrti je prigovor metodi testa "da je štetna jer je građanska psihologija provodila na osnovi takvih ispitivanja određene klasne ciljeve, kao npr. ograničenje nastave za djecu radnika, dokazivanja da su djeca siromašnih klasa manje vrijedna u psihičkom pogledu, dokazivanje da postoje više i niže klase itd." I konačni prigovor bio je da su "testovi standardizirani i zato ne uzimaju dovoljno u obzir individualne razlike" (Bujas, 1952, 13-14).

S obzirom na to da je Jugoslavija bila najvjernija članica Istočnog lagera, a Komunistička partija Jugoslavije najdosljednija sekcija međunarodnog radničkog i komunističkog pokreta, provođenje sovjetskih smjernica, bilo je neupitno, a pogotovo u vremenskom razdoblju prije i neposredno nakon donošenja Prve rezolucije Informbiroa (28. lipnja 1948.), jer KPJ je morala dokazati na djelu svoju vjernost nauci Marxa-Engelsa-Lenjina (i Staljina) (Šeparović, 2017; Previšić, 2014; Živanov, 1977). Stoga ne čudi da su već 1946. krenuli napadi prvo na psihodijagnostičke metode kojima se Zavod koristio, a potom na voditelja Zavoda, Z. Bujasa i njezina suosnivača, stalnog suradnika i savjetnika R. Bujasa. U rubrici "Kulturni život" u Vjesniku Narodnog fronta Hrvatske od 26. kolovoza 1946. objavljen je osvrt, kritika na rad Zavoda za psihofiziologiju rada, a pogotovo na metode psihološkog ispitivanja, koje, prema stavu pisca, trebaju evoluirati "s jedne strane razvojem i bogaćenjem psihološke nauke, a s druge da se prilagode aktualnim oblicima socijalnog života, a koje uvjetuje i politički život pojedinca" (Problem savjetovanja pri izboru zvanja, 1946, 5). Drugim riječima, novim društveno-političkim okolnostima nikako nisu odgovarale dotadašnje tzv. "mehanicističke metode zastarjele psihologije" koje su odgovarale zahtjevima kapitalističke proizvodnje ("Problem savjetovanja pri izboru zvanja", 1946, 5). Ovaj stav jasno se očitovao u raspravama na Psihološkom institutu tijekom 1948. godine, potaknutim odlukama V. kongresa KPJ vezanim uz "borbu za idejnost i čistoću u nauci" (Borba za idejnost ..., 1949, 4), a koje su oblikovale i odluke o programu nastave psihologije. Naime, već 8. siječnja 1949 ., kad je objavljena kritika rada Psihološkog instituta, odnosno vodećih osoba - profesora R. Bujasa i Z. Bujasa - stoji da "u nastavnom planu nema više psihotehnike već psihologija rada, a metode testova prof. dr. Zoran Bujas kritikuje" (Borba za idejnost ..., 1949, 5).

Formalno, Zavod je ukinut zbog reorganizacije državne uprave FNRJ, odnosno Ministarstva rada NR Hrvatske 1. kolovoza 1948. godine (Tarbuk, 1982), no uzevši u obzir gore navedene kritike čelnih osoba i pripadne metodologije rada, te više razina povezanosti Zavoda i Psihološkog instituta na kojem su se događale ideološki obojene promjene, teško je povjerovati da one nisu odredile i samo ukidanje Zavoda. Sličnu sudbinu dijelila je akademska karijera prof. R. Bujasa - osobe koja 
je osnivala ili sudjelovala u osnivanju svih ključnih ustanova za nastanak i razvoj psihologije u Hrvatskoj (i šire). Umirovljen je 1949., formalno, zbog navršenih 70 godina.

Ponovni interes za savjetovanje pri izboru zanimanja može se povezati uz preporuke International Labour Organization (Matešić, 2010), ali i uvođenje socijalističkog samoupravljanja 1950. godine (Horvat, 1970). Stoga je već koncem 1951. u Beogradu održano stručno savjetovanje "Izbor zanimanja" pri Savjetu za narodno zdravlje i socijalnu politiku Vlade FNRJ, na kojem se donosi zaključak da se u svim mjestima gdje postoje uredi za posredovanje rada osnuju i savjetovališta za izbor zanimanja, čemu se i pristupilo tijekom 1950-ih godina. (Bujas, 1952; Tarbuk, 1982).

\section{ZAKLJUČAK}

Tijekom 17 godina rada Stanica za savjetovanje pri izboru zvanja skoro je uspjela preživjeti tri različita društveno-politička i gospodarska sustava, nastojeći svojim djelovanjem, pogotovo na području primijenjene psihologije približiti Hrvatsku što više svjetskim standardima. Njezin doprinos najlakše je kvantitativno predočiti brojem posjetitelja, njih 30.098 odnosno, oko 20.000 onih koji su pristupili liječničkom pregledu i psihološkom testiranju, no značajniji od kvantitativnih pokazatelja su rezultati koje je Stanica/Zavod postigla u postavljanju temelja moderne službe za profesionalnu orijentaciju, kao i razvoju primijenjene psihologije u Hrvatskoj. Njezin razvojni put od utilitarističkog "pravi čovjek na pravom mjestu" do načela "zaposlenja svakome - a radno mjesto prema sposobnostima" odražava nastojanja Stanice/Zavoda da se prilagodi postojećim društvenim zahtjevima i gospodarskim uvjetima. Zahvaljujući tome, ali i činjenici da je zapošljavala kvalitetne stručnjake koji će kasnije činiti jezgru "Zagrebačkog psihologijskog kruga" (Kolesarić, Pavlina, 2005), Stanica će uspješno egzistirati do 1948. unatoč vrlo turbulentnim događanjima tijekom 1940-ih. No, očigledno je činjenica da je Stanica nastala kao produkt građanskog-kapitalističkog sustava bio njezin crimen i uzrok ukidanju. Bez obzira na to, rad Stanice/Zavoda za savjetovanje pri izboru zvanja prilično egzaktno ocrtava gospodarske i socijalne dimenzije hrvatskog građanskog društva tog razdoblja povijesti, no puno veći doprinos njena postojanja i djelovanja jest u razvoju primijenjene psihologije u Hrvatskoj, a sukladno svjetskim standardima psihologijske znanosti i struke. Iz tih razloga u budućim projektima višestruko je opravdano znanstveno odgovoriti na pitanja otvorena u ovom radu i započeti sustavno istraživanje arhivskog gradiva Stanice/Zavoda.

\section{LITERATURA}

Barić, M., Šešo, M. (ur.) (2008). Spomenica Hrvatskoga zavoda za zapošljavanje od 1906. do 2006. 2. dopunjeno izdanje. Zagreb: Hrvatski zavod za zapošljavanje. Dostupno na: 
http://www.hzz.hr/UserDocsImages/SPOMENICA_1906-2006-2.IZDANJE.pdf Pristupljeno: 22. veljače 2018.

Borba za idejnost i čistoću u nauci. Osvrt na predavanja iz psihologije. Studentski list: organ Narodne omladine Zagrebačkog sveučilišta, 8. siječnja 1949. god. V, br. 1, str. 4-5.

Bujas, Z. (1952). Neki problemi u vezi sa osnivanjem savjetovališta pri izboru zanimanja. U: Izbor zanimanja: materijali sa savjetovanja o izboru zanimanja održanog 10. i 11. decembra 1951. (str. 5-19). Beograd: Institut rada pri Savjetu za narodno zdravlje i socijalnu politiku Vlade FNRJ.

Comité français des expositions (1930). Exposition internationale Liège 1930: Catalogue officiel de la section française - grande industrie, sciences et applications, art wallon ancien. Paris.

Čepulić, V. (1938). Izvještaj o radu stanice za savjetovanje o izboru zvanja kod TrgovinskoIndustrijske komore u Zagrebu za godinu 1937. Liječnički vjesnik, 8, 507.

Dugac, Ž. (2005). Zdravstveno prosvjećivanje protiv tuberkuloze u međuratnoj Hrvatskoj. Medicus, 1, 155-171.

Dugački, V. (1973). In memoriam: Dr. phil. et med. Aurel Forenbacher. Priroda, 10, $317-$ 318.

Forenbacher, A. (1943). Osvrt na jedanaest godina savjetovanja kod izbora zvanja u Hrvatskoj. Vjesnik rada, 1-8, 4-13.

Hofgräff, D., Fatović-Ferenčić, S. (2012). Uloga i doprinos Desanke Ristović - Štampar (1882. - 1968.) razvoju Školske poliklinike u Zagrebu (1925. - 1941.). Anali Zavoda za znanstveni i umjetnički rad u Osijeku, sv. 28, 9-24.

Horvat, B. (1970). Privredni sistem i ekonomska politika Jugoslavije. Problemi, teorije, ostvarenja, propusti. Beograd: Institut ekonomskih nauka.

[HR-DAZG-239 Zavod za psihologiju i fiziologiju rada]. (1935-1948). Registraturna pomagala (1 knj.), Spisi (2 kut.), Prijavna dokumentacija (2 knj., 9 kut.), Državni arhiv u Zagrebu, Zagreb.

Kolar, M. (2002). Organizirano obrtništvo u Hrvatskoj 1852. - 2002. Zagreb: Hrvatska obrtnička komora. Dostupno na: https://www.hok.hr/publikacije/hok_publikacije/organizirano_obrtnistvo_u_hrvatskoj_1852_2002 Pristupljeno: 22. veljače 2018.

Kolar, M. (2004). Hrvatski Radiša 1903.-1945.(2003). Zagreb: Hrvatski Radiša, Dom i svijet.

Kolesarić, V., Pavlina, Ž. (2005). Životopis akademika Zorana Bujasa. U: B. Sokač (ur.) Zoran Bujas 1910-2004, Hrvatska akademija znanosti $i$ umjetnosti, Spomenica preminulim akademicima, svezak 129 (str. 13-17). Zagreb: Hrvatska akademija znanosti i umjetnosti. Dostupno na: http://dizbi.hazu.hr/object/view/9mZRcrdnpm_Pristupljeno 21. ožujka 2018.

Martin, J. (2013). L'orientation professionnelle entre science, technique et pratique sociale. Un éclairage historique à partir de l'exemple français, 1900-1940. Actes du congrès de l'Actualité de la recherche en éducation et formation (AREF - AECSE), Laboratoire LIRDEF - EA 3749 - Universités de Montpellier, 2 et 3, août 2013. Dostupno na: https://www.academia.edu/5535456/L_orientation_professionnelle_entre_science_technique_et_pratique_sociale._Un_\% $\% \bar{C} \% \mathrm{~A} 9 \mathrm{clairage}$ historique_o $\% \overline{\mathrm{C}} 3 \% \mathrm{~A} \overline{0}$ partir_de_1_exemple_fran\%C3\%A7ais_1900-1940_Congr\%C3\%A8s_de_1AREF_Montpellier_2013_Pristupljeno: 17. veljače 2018. 
Matešić, K. (2006). Drugo razdoblje razvoja testova i postupaka testiranja u Republici Hrvatskoj od 1932. do 1948. godine. Suvremena psihologija, 9(1), 89-108.

Matešić, K. (2010). Psihodijagnostička sredstva. Jastrebarsko: Naklada Slap.

Matešić, K. (2011). Osamdeset godina primjene psiholoških testova u službi profesionalnog usmjeravanja u Republici Hrvatskoj. U: M. Zećirević (ur.) 80 godina cjeloživotnog profesionalnog usmjeravanja u Republici Hrvatskoj: Novi izazovi i pristupi: Zbornik radova (str. 12-15). Zagreb: Hrvatski zavod za zapošljavanje. Dostupno na: http://arhiva.mobilnost.hr/prilozi/05_1341303476_Zbornik_radova_konferencije_80_god_ CPU_u_RH.pdf Pristupljeno: 22. ožujka 2018.

Matešić, K. (2017). HR-DAZG-239 Zavod za psihologiju i fiziologiju rada. Suvremena psihologija, 20(2), 197-206.

Pavlina, Ž., Kolesarić, V. (1987). Značenje Psihologijskog instituta Zagrebačkog sveučilišta za razvoj psihologije u nas. Primijenjena psihologija, 8, 25-35.

Petz, B. (2005). Zoran Bujas u mojim sjećanjima na neka razdoblja zajedničkog rada. U: B. Sokač (ur.) Zoran Bujas 1910-2004, Hrvatska akademija znanosti i umjetnosti, Spomenica preminulim akademicima, svezak 129 (str. 43-52). Zagreb: Hrvatska akademija znanosti i umjetnosti. Dostupno na: http://dizbi.hazu.hr/object/view/9mZRcrdnpm Pristupljeno 21. ožujka 2018.

Previšić, M. (2014). Informbiroovska emigracija. Historijski zbornik, 1, 171-186.

Problem savjetovanja pri izboru zvanja. Povodom članka "Svaki na svoje mjesto" objavljenog u Narodnom listu od 18. kolovoza 1946. Vjesnik Narodnog fronta Hrvatske, 25. kolovoza 1946. god. VI, broj 441, str. 5.

Skrb za priradnu i radničku mladež. Osnivanje Državnog Savjetodavnog zavoda za izbor zvanja. Gospodarstvo: ogledalo hrvatskog gospodarskog života, 2. lipnja 1942. god. II, broj 117, str. 2.

Stipčević, A. (ur.) (1989). Cuvaj, Adolf. U: Hrvatski biografski leksikon, sv. 2, Bj-C (str. 757758). Zagreb: Jugoslavenski leksikografski zavod "Miroslav Krleža"

Stipetić, V. (2012). Dva stoljeća razvoja hrvatskog gospodarstva (1820.-20015.). Zagreb: Hrvatska akademija znanosti i umjetnosti.

Šarić, M., Šarić B. (2003). Radna sposobnost - pristup i kriteriji u ocjeni. Arhiv za higijenu rada i toksikologiju, 4, 297-304.

Šeparović, A. (2017). ULUH oko Informbiroa: dinamika ideološko-političkog pritiska u likovnom stvaralaštvu. Peristil, 1, 103-116.

Šešo, Z. (2000). Počeci djelovanja službe za zapošljavanje u Hrvatskoj. Revija za socijalnu politiku, 2, 175-182. https://doi.org/10.3935/rsp.v7i2.256 Pristupljeno: 22. veljače 2018.

Šugar, I. (ur.) (1998). Festetić, Miroslav. U: Hrvatski biografski leksikon, sv. 4, E-Gm (str. 193). Zagreb: Leksikografski zavod Miroslava Krleže

Šugar, I. (ur.) (1998). Forenbacher, Aurel. U: Hrvatski biografski leksikon, sv. 4, E-Gm (str. 325-326). Zagreb: Leksikografski zavod Miroslava Krleže.

Tarbuk, D. (1982). Stanica za savjetovanje pri izboru zvanja. Zapošljavanje: delegatski informator samoupravnih interesnih zajednica i Udružene samoupravne interesne zajednice za zapošljavanje Zagreb, 23, 7-18. 
Težak, S., Markovac, J. (ur.) (1971). Pedagoška akademija Zagreb 1919-1969. Zagreb: Pedagoška akademija.

Trgovinsko-industrijska komora u Zagrebu (1933). Izvještaj o radu Stanice za savjetovanje pri izboru zvanja za godinu 1932. (Posebni otisak iz Izvještaja Trgovinsko-industrijske komore u Zagrebu za god. 1932.) Zagreb.

Trgovinsko-industrijska komora u Zagrebu (1934). Izvještaj o radu Stanice za savjetovanje pri izboru zvanja za godinu 1933. (Posebni otisak iz Izvještaja Trgovinsko-industrijske komore u Zagrebu za god. 1933.) Zagreb.

Trgovinsko-industrijska komora u Zagrebu (1935). Izvještaj o radu Stanice za savjetovanje pri izboru zvanja za godinu 1934. Zagreb.

Trgovinsko-industrijska komora u Zagrebu (1936). Izvještaj o radu Stanice za savjetovanje pri izboru zvanja za godinu 1935. Zagreb.

Trgovinsko-industrijska komora u Zagrebu (1937). Izvještaj o radu Stanice za savjetovanje o izboru zvanja kod Trgovinsko-industrijske komore u Zagrebu za godinu 1936. Zagreb.

Trgovinsko-industrijska komora u Zagrebu (1938). Izvještaj o radu Stanice za savjetovanje o izboru zvanja kod Trgovinsko-industrijske komore u Zagrebu za godinu 1937. Zagreb.

Trgovinska komora u Zagrebu (1939). Izvještaj o radu Stanice za savjetovanje o izboru zvanja kod Trgovinsko-industrijske komore u Zagrebu za godinu 1938. Zagreb.

Trgovinska komora u Zagrebu (1940). Izvještaj o radu Stanice za savjetovanje o izboru zvanja kod Trgovinske komore u Zagrebu za godinu 1939. Zagreb.

Vukasović, A. (2015). Likovi istaknutih hrvatskih pedagoga: Ivan Filipović, Vjekoslav Koščević, Stjepan Matičević, Pavao Vuk-Pavlović, Stjepan Pataki, Zlatko Pregrad, Pero Šimleša. Zagreb: Školske novine.

Zakonska odredba o naučnicima i mladim radnicima i namještenicima od 30. travnja 1942. Nezavisna Država Hrvatska, Zakoni, zakonske odredbe i naredbe proglašene od 8. travnja do 30. travnja 1942., knj. XV (svezak 141.-150). Zagreb: Knjižara St. Kugli.

Zaštita najmladjih u hrvatskom priradu. Povodom zakonske odredbe o naučnicima, mladim radnicima i mladim namještenicima. Gospodarstvo: ogledalo hrvatskog gospodarskog života, 7. svibnja 1942. god. II, broj 98, str. 1.

Živanov, S. (1977). Tito i jugoslovenski sukob sa slaljinističkom hegemonističkom politikom Informbiroa /1948/ 1953/. Politička misao, 4, 523-544.

Žuškin, E., Mustajbegović, J., Dečković-Vukres, V., Zavalić, M., Bogadi-Šare, A., Poplašen-Orlovac, D., Prokić, A., Bubaš, M. (2006). Prepoznavanje potrebe zdravstvene skrbi o radnicima tijekom povijesti. Arhiv za higijenu rada i toksikologiju, 2, 201-212. 


\title{
THE ESTABLISHMENT AND ACTIVITIES OF THE VOCATIONAL COUNSELLING CENTER 1931-1941 - THE BEGINNING OF APPLIED PSYCHOLOGY IN CROATIA
}

\begin{abstract}
The Vocational Counseling Center was founded by decree of the Executive Board of the Office for Trade Improvement of the Chamber of Commerce, Industry and Trade in Zagreb on June $19^{\text {th }} 1931$. The main task of the Center was to counsel young people in their choice of trade and crafts professions as well as professional schools, based on the medical examination of physical development and health and on the psychological assessment of their abilities and motivation. For seventeen years, the Vocational Counseling Center (later renamed Vocational Counseling Department) was visited by more than 30,000 people, whereby more than 20,000 were psychologically tested. Although the number of examined and tested persons drastically increased in the last years of the Center/Department activities, the Department had been closed and psychotechnics (the prevalent activity of the Department) were excluded from the curriculum of the Institute of Psychology at the Faculty of Humanities and Social Sciences, University of Zagreb.

Keywords: Chamber of Commerce and Industry, Vocational Counseling Center, Vocational Counseling Department, Office for Work Psychology and Physiology, psychotechnics (applied psychology), Hrvatski Radiša
\end{abstract}

Primljeno: 22. 04. 2018. 
Prilog 1.

\section{PRAVILNIK STANICE ZA SAVJETOVANJE PRI IZBORU ZVANJA (1931.)*}

\section{$\S 1$.}

"Stanica za savjetovanje pri izboru zvanja je sastavni dio Zavoda za unapređivanje obrta Komore za trgovinu, obrt i industriju u Zagrebu.

Teritorijski djelokrug stanice proteže se zasad samo na područje grada Zagreba.

\section{$\S 2$.}

Zadaća je stanice da savjetuje mladeži i odraslima kod izbora privrednog zvanja ispitujući njihovu fizičku i psihičku sposobnost, i tako sprečava stupanje u pojedina privredna zvanja onima, koji nemaju za to fizičkih i psihičkih preduvjeta.

\section{$\S 3$.}

Savjetovanje kod izbora zvanja je javna socijalna ustanova namijenjena mladeži, koja neposredno stoji pred izborom zvanja, a jednako i odraslima, koji bi, ma iz kojeg razloga, bili prinuđeni promijeniti zvanje.

\section{$\S 4$.}

Savjetovanje pri izboru zvanja mora biti jednako psihološki osnovano, kao i prožeto jakim socijalnim osjećajem, vodeći brigu podjednako o psihičkom pripremanju mladeži za kasniji život u odabranom zvanju, kao i o najpovoljnijem uređenju njezinoga stručnog obrazovanja.

\section{$\S 5$.}

Kod savjetovanja pri izboru zvanja valja u prvom redu utvrditi sposobnost u tjelesnom, psihičkom (intelektualnom i moralnom) i gospodarskom pogledu.

$\S 6$.

Utvrđivanje tjelesne sposobnosti za izvjesna zvanja stvar je liječnika, u gdjekojim slučajevima dapače ne samo jednoga već i više specijalista.

\section{$\S 7$.}

Psihološko ispitivanje sposobnosti treba da vrši kvalifikovan i iskusan psiholog. $\S 8$.

Liječnik, psiholog i savjetnik pri izboru zvanja imadu se u svojim opažanjima i stručnim mišljenjima stalno popunjavati.

* Izvor: TIKZ, 1933, 4-6 


\section{$\S 9$.}

Savjetnik pri izboru zvanja je šef Stanice za savjetovanje kod izbora zvanja i kao takav organ Zavoda za unapređivanje obrta Komore za trgovinu, obrt i industriju u Zagrebu.

\section{$\S 10$.}

Šefu Stanice podređeni su kao saradnici psiholog i liječnik, koji upravljaju psihološkim, odnosno liječničkim laboratorijima Stanice.

\section{$\S 11$.}

Da bi i škole sudjelovale kod savjetovanja pri izboru zvanja, Stanica će 4-5 mjeseci prije roka otpusta učenika iz škole dostaviti školskim upravama naročite upitnice za izbor zvanja.

Te upitnike ispunjava dijelom mladež, dijelom školska vlast, a dijelom školski liječnik.

\section{$\S 12$.}

Školski liječnik ograničit će se u svom ispitivanju, u najboljem slučaju, na negativan izbor, t.j. on će s općega liječničkog stanovišta utvrditi da li je tjelesni razvoj učenika dobar, prosječan ili ispod prosjeka; nadalje, da li je učenik sposoban za zvanje koje želi odabrati ili nije odmah sposoban, nego treba da izvjesno vrijeme pričeka s ulaženjem u odabrano zvanje; napokon, liječnik ima da ispita zdravstveno stanje učenika i s gledišta eventualnih fizičkih nedostataka ispitanika. U posljednjem slučaju može školski liječnik još predložiti, od kojih se zvanja ima učenika odalečiti.

\section{$\S 13$.}

Kod onih zvanja, koja iziskuju naročite duševne i tjelesne sposobnosti, ima se Stanica pobrinuti za liječnika specijalistu, odnosno psihologa, koji je po mogućnosti ujedno i obrtno-higijenski, odnosno obrtno-medicinski obrazovan.

\section{$\S 14$.}

Svaka liječnička pregledba, koja se vrši u ime ili na traženje Stanice, ima da poda jasnu sliku o zdravstvenom stanju pregledane osobe, a naročito treba da pruži prognozu njezinog fizičkog razvitka.

\section{$\S 15$.}

Liječnička je pregledba potrebna:

1. kod onih koji traže savjet pri izboru zvanja, a nisu pregledani po školskom liječniku;

2. kod onih koji su po školskom liječniku doduše označeni posve besprijekorni i sposobni za zvanje:

a) ako savjetnik zvanja sam sumnja u zdravstvenu sposobnost $i$

b) ako se odabire zvanje koje je osobito opasno za zdravlje; 
3. kod onih koji imadu bilo kakav fizički nedostatak, t.j.:

a) svi bolesni na plućima i sumnjivi na tuberkulozu,

b) svi bolesni na srcu,

c) svi kod kojih postoji mogućnost da se liječenjem ukloni izvjesni nedostatak (slaboća),

d) svi oni koji odabiru takvo zvanje, koje može imati s obzirom na njihovo zdravlje, nepovoljne posljedice, a koje savjetnik pri izboru zvanja ne može predvidjeti.

\section{$\S 16$.}

Savjetnik pri izboru zvanja može, u svrhu izmjene misli, prisustvovati liječničkim pregledima onih koji traže savjet pri izboru zvanja.

\section{$\S 17$.}

Kod Stanice za savjetovanje pri izboru zvanja postoji posebno odjeljenje za psihološko ispitivanje sposobnosti. Na čelu toga odjeljenja stoji psiholog stručnjak. Ovo je odjeljenje dužno podržavati vezu s Institutom za eksperimentalnu psihologiju univerziteta Kraljevine Jugoslavije u Zagrebu.

\section{$\S 18$.}

Ovo odjeljenje ima se uglavnom ograničiti na praktično ispitivanje, $i$ to na osnovu metoda koje su već znanstveno utvrđene.

\section{$\S 19$.}

Psihološko se ispitivanje sposobnosti vrši po potrebi, a naročito u ovim slučajevima:

1. kod onih koji se žele posvetiti osobito kvalifikovanim zvanjima (precizni mehaničari, optičari, proizvođači alata itd.);

2. kod onih o kojima savjetnik pri izboru zvanja želi imati veću jasnoću o njihovim duševnim sposobnostima;

3. kod onih koje šalju pojedine tvrtke ili privredne organizacije, s kojima su sklopljena posebna utanačenja za ispitivanje sposobnosti budućih naučnika ili namještenika.

Potrebu psihološkog ispitivanja ustanovljuje psiholog Stanice.

$$
\S 20 .
$$

Ispitivački nalazi učitelja, liječnika i psihologa pri utvrđivanju sposobnosti pružaju u svom rezultatu podlogu, na temelju koje onda savjetnik pri izboru zvanja utvrđuje sveukupnu sposobnost ispitanog lica.

Pri izvršenju tih dužnosti ima savjetnik pri izboru zvanja da uzme u obzir sklonosti i vještine ispitanog, kao i gospodarske prilike odabranog zvanja.

\section{$\S 21$.}

Savjetnik pri izboru zvanja treba da drži stalne veze s privrednim radionicama i zavodima, nadalje s privrednim organizacijama te burzama rada, komorama 
i obrtnim zborovima, sa svrhom da bude obaviješten o raspoloživim mjestima za naukovanje naučnika.

\section{$\S 22$.}

Dužnost je savjetnika pri izboru zvanja upućivati budućeg naučnika u prava i dužnosti, koje izviru iz naukovnog ugovora, te pozivati ga na svjesno vršenje njegovih dužnosti.

\section{$\S 23$.}

Djelatnost savjetnika pri izboru zvanja sastoji se u savjetovanju mladeži i odraslih lica, koja stoje pred izborom zvanja, odnosno pred promjenom zvanja. Ova se djelatnost vrši individualnim ispitivanjem tjelesnih i duševnih sposobnosti pojedinčevih za izvjesno zvanje, pazeći pri tome na sve zahtjeve zvanja i na gospodarski položaj onoga koji traži savjet, kao i na gospodarske izglede u pojedinim zvanjima, ukoliko se to može predvidjeti.

Pored toga dužnost je savjetnika pri izboru zvanja da drži stručno-informativna predavanja na sastancima roditelja, učitelja, privrednih organizacija; nadalje je njegova dužnost da sakuplja materijal za nauku o zvanjima.

\section{$\S 24$.}

Ovaj Pravilnik odobren je na osnovu §8. Pravilnika Zavoda za unapređivanje obrta po upravnom odboru Zavoda u sjednici od 27. augusta 1931. godine." (Br. 137/ad 21/Z.O. 1931.) 